\title{
Penerapan Pembelajaran IPA Berbasis Pendekatan Saintifik pada Masa Pandemi COVID-19 di SMP Se-Kabupaten Ngawi
}

\author{
Arifian Dimas \\ Program Studi Pendidikan IPA, STKIP Modern Ngawi, Afd.dimas@gmail.com
}

\begin{abstract}
Abstrak
Pandemi COVID-19 memberikan dampak secara signifikan pada kegiatan pembelajaran guru dan peserta didik disekolah. Maka dari itu diperlukan kajian mengenai kegiatan pebelajaran di masa pandemi COVID-19. Penelitian ini bertujuan untuk mengetahui penerapan pembelajaran IPA berbasis pendekatan saintifik pada masa pandemi COVID-19 di SMP Se-Kabupaten Ngawi. Metode yang digunakan dalam penelitian ini adalah deskriptif kualitatif. Populasi dalam penelitian adalah siswa SMP se-Kabupaten Ngawi. Sampel yang digunakan dalam penelitian adalah siswa dari 5 sekolah diantaranya siswa SMP Negeri 3 Ngawi ,SMP Negeri 2 Ngawi, SMP Negeri 5 Ngawi, SMP Negeri 1 Kedunggalar, SMP Negeri 1 Karangjati, SMP Negeri 2 Paron. Instrumen Penelitian yang digunakan adalah lembar observasi pembelajaran, lembar wawancara, dan angket. Teknik analisis data yang digunakan adalah teknik triangulasi. Hasil penelitian menunjukkan bahwa sebagian besar penerapan pembelajaran berbasis saintifik tidak terlaksana dengan maksimal dimasa pandemi COVID-19.
\end{abstract}

Kata Kunci : Pembelajaran IPA, Pendekatan Saintifik, Pandemi COVID-19.

\section{PENDAHULUAN}

Pembelajaran berbasis pendekatan saintifik adalah bentuk kegiatan pembelajaran yang menekankan pada pengalaman belajar dalam bentuk mengamati, menanya, mengumpulkan informasi (mencoba /eksperimen), dan mengomunikasikan (Permendikbud No. 103 Th. 2014). Kegiatan dalam pembelajaran berbasi saintifik dapat diintegrasikan pada penerapan metode ilmiah. Langkah-langkah (sintaks) pendekatan saintifik disajikan pada Tabel.1 berikut:

Tabel 1. Sintaks Pendekatan Saintifik

\begin{tabular}{ll}
\hline Langkah & Kegiatan Belajar \\
\hline Mengamati & Membaca, mendengar, \\
& menyimak,melihat \\
\hline Menanya & Bertanya terkait \\
& informasi yang diberikan \\
& oleh guru untuk \\
& memperoleh informasi \\
& tentang konsep yang \\
& dipelajari. \\
\hline Mengumpulkan & Melakukan percobaan, \\
Informasi/ekperi & wawancara, mengkaji \\
men & sumber lain, pengamatan \\
& pada objek, melakukan \\
& kegiatan survey.
\end{tabular}

\begin{tabular}{|c|c|}
\hline Mengolah & Melakukan \\
\hline Inforn & $\begin{array}{lr}\text { terhadap informasi yang } \\
\text { diperoleh } & \text { sehingga } \\
\text { mendapatkan } & \text { konsep } \\
\text { yang dipelajari. } & \end{array}$ \\
\hline $\begin{array}{l}\text { Mengomunikasik } \\
\text { an }\end{array}$ & $\begin{array}{l}\text { Menjelaskan terkait hasil } \\
\text { dari percobaan atau } \\
\text { eksperimen yang sudah } \\
\text { dianalisis secara tertulis, } \\
\text { lisan, atau media } \\
\text { lainnya. }\end{array}$ \\
\hline
\end{tabular}

Sumber : Permendikbud no 81 A Tahun 2013

Metode ilmiah adalah proses kegiatan yang dilakukan secara sistematis untuk mengetahui informasi melalui kegiatan ilmiah. Langkah ilmiah yang dilakukan yaitu melalui pengumpulan data melalui observasi atau percobaan, mengolah data, menganalisis data, memformulasikan data, menguji hipotesis, dan menyimpulkan (Daryanto, 2014). Pada pembelajaran dengan menerapkan pendekatan saintifik bertujuan agar peserta didik secara aktif dapat memahami konsep, hukum, atau prinsip secara mandiri.

Pandemi COVID-19 berdampak secara signifikan diberbagai bidang kehidupan manusia. Aktivitas manusia telah berubah 
total,mengalami kebiasaan baru yaitu sosial distancing. Social distancing merupakan aktivitas manusia yang hanya dilakukan dari rumah melalui jaringan. Kebijakan sosial distancing yang diterapkan bertujuan untuk membatasi interaksi manusia dan mencegah keramaian agar terhindar dari penyebaran virus corona. Akibat dari kegiatan social distancing ini memberikan perubahan kegiatan pembelajaran di sekolah. Sebelumnya kegiatan pembelajaran dilakukan secara tatap muka dikelas berubah menjadi kegiatan pembelajaran dalam jaringan (daring). Perubahan kegiatan pembelajaran harus diterima oleh guru, siswa, dan orang tua (Masrokhah, 2020).

Pada situasi pandemi COVID-19 kurikulum harus disesuaikan dengan keadaan. Guru dinstruksikan untuk mengajar melalui media pembelajaran online atau dalam jaringan (daring). Pembelajaran daring mengharuskan seorang guru harus berkreasi dan berinovasi agar proses transfer pengetahuan kepada peserta didik dapat berjalan dengan benar (Gusty dkk, 2020). Meskipun pembelajaran daring disesuaikan dengan format sekolahan masing masing, guru diberikan kebebasan untuk melaksanakan kegiatan pembelajaran secara daring sesuai dengan strategi yang digunakan. Namun, banyak siswa yang mengalami permasalahan dalam pembelajaran daring diantaranya jenuh, tidak bersemangat, depresi, jaringan internet yang tidak lancar dan kondisi belajar kurang baik. (Kapasia dkk, 2020).

Salah satu pembelajaran yang menggunakan strategi pembelajaran yang menuntut siswa aktif adalah pembelajaran IPA. Pembelajaran IPA pada dasarnya menuntut siswa untuk menemukan konsep yang dipelajari peserta didik melalui proses ilmiah. Peran guru dalam pembelajaran IPA hanya sebagai fasilitator dan siswa sepenuhnya aktif dalam melaksanakan proses pembelajaran (Student Center. Hutahaean, R., Harahap, M. B., \& Derlina. (2017) menunjukkan bahwa siswa yang menerapkan strategi inkuiri memiliki pemahaman konsep sains yang lebih baik daripada siswa yang menerapkan strategi tradisional. Penerapan strategi inkuiri juga berpengaruh terhadap peningkatan motivasi dan hasil belajar IPA (Abdi, 2014; Lintuan, Chin, Tsai, \& Cheng, 2005).

Berdasarkan uraian permasalahan diatas peneliti akan mengkaji penerapan pembelajaran berbasis pendekatan saintifik pada masa pandemi COVID-19 di SMP se-Kabupaten Ngawi khususnya pada mata pelajaran IPA.

\section{METODE}

Penelitian ini menggunakan metode deskriptif kualitatif. Populasi dalam penelitian adalah siswa SMP se-Kabupaten Ngawi. Sampel yang digunakan dalam penelitian adalah siswa dari 5 sekolah diantaranya siswa SMP Negeri 3 Ngawi,SMP Negeri 2 Ngawi, SMP Negeri 5 Ngawi, SMP Negeri 1 Kedunggalar, SMP Negeri 1 Karangjati, SMP Negeri 2 Paron. Instrumen Penelitian yang digunakan adalah lembar observasi pembelajaran, lembar wawancara, dan angket. Teknik analisis data yang digunakan adalah teknik triangulasi.

\section{HASIL DAN PEMBAHASAN}

Berdasarkan hasil penelitian yang telah dilakukan diperoleh persentase hasil ketercapaian pelaksanaan pembelajaran menggunakan pendekatan saintifik sebagai berikut:

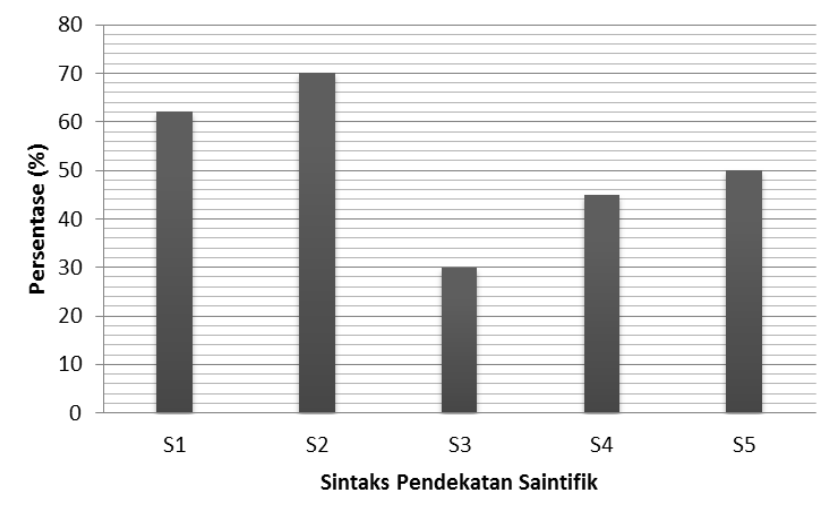

Grafik 1. Ketercapaian Pendekatan Saintifik 
Keterangan :

S1 : Mengamati

S2: Menanya

S3 : Mengumpulkan Informasi/Eksperimen

S4 : Mengolah Informasi

S5 : Mengomunikasikan

Pada grafik 1. menunjukkan bahwa keterlaksanaan pembelajaran berbasis pendekatan saintifik belum sepenuhnya tercapai dengan baik. Pada pelaksanaan sintaks mengamati tercapai $62 \%$, menanya tercapai $70 \%$, mengumpulkan informasi/eksperimen tercapai 30\%, mengolah informasi $45 \%$, dan mengomunikasikan tercapai $50 \%$. Ketercapaian tertinggi pada sintaks menanya yaitu sebesar 70\%. Hal ini menunjukkan bahwa sebagian siswa masih aktif bertanya dalam proses pembelajaran. Sebaliknya, ketercapaian terendah pada sintaks mengumpulkan informasi atau bereksperimen yaitu sebesar 30\%. Hal ini menunjukkan bahwa pembelajaran sebagian besar belum mengarahkan siswa untuk mengumpulkan informasi atau bereksperimen. Hasil ini sesuai dengan penelitian dari Kapasia, N., Paul, P., Roy, A., dkk (2020) yang mengatakan bahwa pada masa pandemi COVID-19 guru tidak bisa mengetahui pelaksanaan langkah-langkah pembelajaran berbasis penemuan secara baik karena tidak berinteraksi secara langsung.Selain itu, kurangnya pengawasan dari orang tua dengan baik juga menjadi faktor keberhasilan proses pembelajaran. Berikut hasil wawancara yang dilakukan dengan guru :

\section{Peneliti : Bagaimana pelaksanaan pembelajaran yang dilakukan disekolah ini?}

Guru : Pembelajaran dilakukan secara online atau daring.

Peneliti : Kendala apa saja yang dihadapi?

Guru : Kami tidak bisa mengarahkan siswa untuk melakukan percobaan atau eksperimen secara langsung

\section{di laboratorium.}

\section{Peneliti : Apakah anda tidak menggunakan percobaan berbasis virtual? \\ Guru : Tidak}

Hasil wawancara dengan guru menunjukkan bahwa pembelajaran secara daring memberikan permasalahan bagi pelaksanaan pembelajaran berbasis pendekatan saintifik. Guru masih kesulitan dalam melaksanakan langkah bereksperimen kepada siswa karena tidak tatap muka. Selain itu alat dan bahan percobaan tidak bisa diakses oleh siswa. Hal ini menyebabkan siswa tidak bisa bereksperimen sehingga ketercapaian sintaks mengumpulkan informasi/ eksperimen sangat rendah. Adapun model pembelajaran yang digunakan guru dalam pembelajaran daring ditunjukkan pada grafik. 2 berikut:

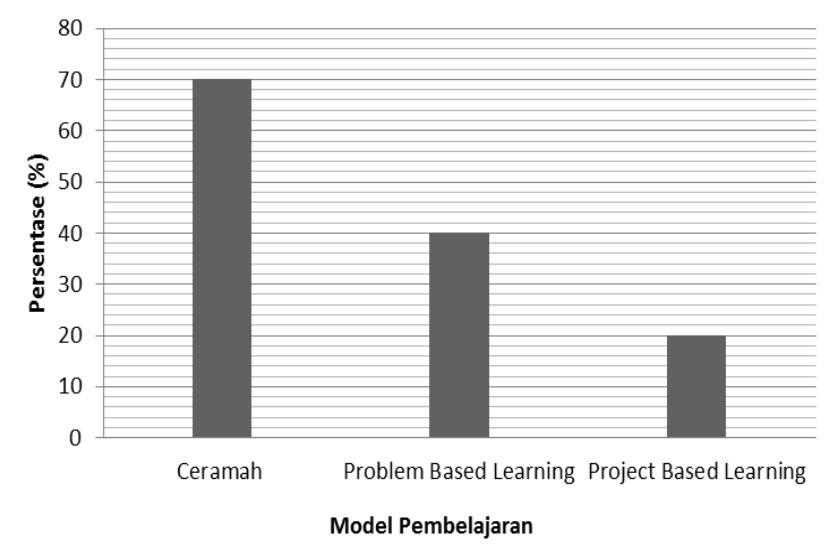

Grafik 2. Model Pembelajaran

Pada Grafik.2 Menunjukkan bahwa persentase tertinggi yaitu metode atau model pembelajaran yang digunakan adalah ceramah sebesar $70 \%$. Pembelajaran dengan metode ceramah dianggap sebagai metode yang efektif dalam pelaksanaan pembelajaran daring. Guru menyampaikan materi dengan menggunakan PPT atau Slide yang langsung dapat dilihat oleh siswa. Namun, dalam pembelajaran menggunakan metode ceramah siswa tidak melakukan percobaan secara langsung. Berikut adalah hasil wawancara yang dengan guru: 


\begin{tabular}{|c|c|}
\hline Peneliti & $\begin{array}{l}\text { : Apakah pembelajaran IPA disini } \\
\text { sudah menggunakan pendekatan } \\
\text { saintifik? }\end{array}$ \\
\hline Guru & $\begin{array}{l}\text { Sudah. Namun pada waktu } \\
\text { pandemi seperti sekarang ini kami } \\
\text { mengalami kesulitan dalam } \\
\text { pelaksanaannya. }\end{array}$ \\
\hline Peneliti & $\begin{array}{l}\text { Lalu bagaimana pelaksanaan } \\
\text { pembelajaran IPA pada waktu } \\
\text { pendemi seperti ini? }\end{array}$ \\
\hline Guru & $\begin{array}{l}\text { Kebanyakan dilakukan dengan } \\
\text { metode ceramah karena lebih } \\
\text { efektif untuk mengejar materi } \\
\text { pelajaran. }\end{array}$ \\
\hline Peneliti & $\begin{array}{l}\text { Baik terima kasih atas } \\
\text { informasinya. }\end{array}$ \\
\hline
\end{tabular}

Berdasarkan hasil wawancara diperoleh informasi bahwa menurut sebagian besar guru, penggunaan metode ceramah pada saat pembelajaran daring lebih efektif untuk menyelesaikan materi pelajaran. Siswa difokuskan kepada penyelesaian materi tanpa dilatihkan bereksperimen untuk menemukan konsep yang dipelajari. Hal ini akan berpengaruh kepada kemampuan pemahaman konsep siswa pada materi yang dipahami. Pemahaman konsep seharusnya diperoleh siswa dengan langkah melakukan eksperimen baik secara langsung ataupun virtual. Guru dituntut untuk tetap kreatif dan inovatif dalam pelaksanaan pembelajaran meskipun dilaksanakan secara daring.

Hasil belajar siswa merupakan tujuan utama indikator pembelajaran tercapai dengan baik. Jika guru melaksanakan pembelajaran secara saintifik dengan baik maka siswa juga akan terbiasa dan kemudian menjadi mandiri dalam menemukan konsep yang mereka pelajari. Hal ini sejalan dengan hasil penelitian Moch Adi Sucipto (2016) yaitu penerapan pembelajaran saintifik dapat meningkatkan hasil belajar siswa jika dilaksanakan sesuai dengan baik. Penelitian yang dilakukan di SMK Krian 2 Sidoarjo dengan menerapkan pembelajaran dengan pendekatan saintifik memberikan hasil 96\% siswa telah lulus dari Standar Kelulusan Minimal yang ditentukan.

Selain itu hasil penelitian Nur Alamsyah (2016) bahwa pembelajaran yang menggunakan pendekatan saintifik dapat meningkatkan aktivitas siswa, kreativitas siswa, dan hasil belajar siswa. Aktivitas siswa ditingkatkan melalui tindakan sebanyak 3 siklus dan menghasilkan $94 \%$ siswa menjadi aktif dalam pembelajaran. Kreativitas meningkat menjadi $100 \%$ pada siklus III. Hasil belajar meningkat pada siklus III menjadi $92 \%$ tuntas.

Berdasarkan hasil penelitian dan kajian terhadap hasil penelitian dari orang lain, maka pembelajaran yang menggunakan pendekatan saintifik jika dilaksanakan dengan baik dan maksimal dapat meningkatkan berbagai variabel pembelajaran yang diharapkan pada abad 21 . Variabel tersebut diantaranya keaktifan siswa, kreatifitas siswa, kemampuan berpikir kritis, kemampuan memahami konsep, dan lain sebagainya.

Temuan dari kajian penelitian ini dapat digunakan sebagai dasar pendidik atau guru untuk dapat berinovasi pada proses pembelajaran dalam situasi apapun. Sehingga keterlaksanaan pembelajaran berbasis penemuan atau saintifik dapat melatihkan siswa untuk menghadapi tantangan abad 21.

\section{PENUTUP}

\section{Simpulan}

Penerapan pembelajaran dengan pendekatan saintifik di SMP Se-Kabupaten Ngawi belum terlaksana secara maksimal. Pandemi COVID-19 menyebabkan pembelajaran tidak bisa dilaksanakan secara tatap muka. Keadaan ini menyebabkan sintaks pendekatan saintifik tidak bisa dilaksanakan dengan baik.

\section{Saran}

1. Guru sebaiknya melakukan pembelajaran berbasis saintifik meskipun pembelajaran 
dilakukan secara daring. Hal ini bisa dilakukan dengan berkreasi dan berinovasi dengan memanfaatkan media berbasis ICT.

2. Selama kegiatan pembelajaran menggunakan pendekatan saintifik berlangsung, sebaiknya guru dapat mengarahkan dan membimbing jalannya diskusi dengan baik.

3. Guru harus membagi kelompok secara heterogen sehingga diskusi dapat berjalan dengan baik.

4. Guru sebaiknya membimbing siswa dengan baik dalam penyusunan laporan agar sistematis dan terarah.

\section{DAFTAR PUSTAKA}

Abdi, A. (2014). The effect of inquiry based learning method on student academic achievement in science course. Universal Journal of Education Research, 2(1), 3741.

Alamsyah, N. (2016) Penerapan pendekatan saintifik untuk meningkatkan kreativitas dan hasil belajar siswa dalam mata pelajaran IPA. Jurnal Pendidikan Vol (1) No $181-88$

Daryanto. (2014). Pendekatan Pembelajaran Saintifik Kurikulum 2013. Yogyakarta: Penerbit Gava Media.

Gusty, S., Nurmiati, N., Muliana, M., Sulaiman, O. K., Ginantra, N. L. W. S. R., Manuhutu, M. A., Sudarso, A., Leuwol, N. V., Apriza, A., \& Sahabuddin, A. A.. Belajar Mandiri: Pembelajaran Daring di Tengah Pandemi Covid-19. Yayasan Kita Menulis. (2020)

Hutahaean, R., Harahap, M. B., \& Derlina. (2017). The effect of scientific inquiry learning model using macromedia flash on strudent's concept understanding and science process skills in senior high school. IOSR Journal of Research \& Method in Education (IOSR-JRME), 7(4), 29-37.

Kapasia, N., Paul, P., Roy, A., Saha, J., Zaveri, A., Mallick, R., Barman, B., Das, P., \& Chouhan, P.. Impact of lockdown on learning status of undergraduate and postgraduate students during COVID19 pandemic in West Bengal, India. Children and Youth Services Review, (2020). 116, 105, 194.

Kemendikbud. 2013. Lampiran Permendikbud Nomor 81A Tahun 2013 Tentang Implementasi Kurikulum Pedoman Umum Pembelajaran. Jakarta: Kementerian Pendidikan dan Kebudayaan RI.

Kemendikbud. 2014. Permendikbud Nomor 103 Tahun 2014 Tentang Pembelajaran Pada Pendidikan Dasar dan Pendidikan Menengah Jakarta: Kementerian Pendidikan dan Kebudayaan RI.

Lintuan, H., Chin, C-C., Tsai, C-C, \& Cheng, SF. (2005). Investigating the effectiveness of inquiry instruction on the motivation of different learning styles students. International Journal of Mathematic Education, 3, 541-566.

Masrokhah, M. Evaluasi Implementasi Kurikulum 2013 Dalam Pembelajaran Online Selama Masa Pandemi Covid-19 Di Sdn Bintoro 5 Kabupaten Demak. (2020)

Sucipto, M.A. (2016). Analisis penerapan pendekatan saintifik terhadap peningkatan kemampuan berkomunikasi, berkolaborasi, dan hasil belajar Siswa kelas XI TKR SMK Krian 2 Sidoarjo. JPTM. Vol (05) 2 31-39 